\title{
Carbon Ion and Proton Beam Irradiation of a Normal Human TK6 Lymphoblastoid Cell Line Within a Magnetic Field of I.0 Tesla [Corrigendum]
}

Yudhistiara B, Weber KJ, Huber PE, et al. Cancer Manag The authors apologize for this error. Res. 2019;11:8327-8335.

The authors have advised the article type shown on page 8327 is incorrect. The text "REVIEW" should read "ORIGINAL RESEARCH".

\section{Publish your work in this journal}

Cancer Management and Research is an international, peer-reviewed open access journal focusing on cancer research and the optimal use of preventative and integrated treatment interventions to achieve improved outcomes, enhanced survival and quality of life for the cancer patient.

The manuscript management system is completely online and includes a very quick and fair peer-review system, which is all easy to use. Visit http://www.dovepress.com/testimonials.php to read real quotes from published authors. 